\title{
Estimation of crop coefficient for Marigold (Tagetes erecta (L.)) under drip irrigated greenhouse
}

\section{E. Sujitha* \\ Institute of Agriculture, Tamil Nadu Agricultural University, Kulmulur, Trichy (Tamil Nadu), India}

\section{K. Shanmugasundaram}

Department of Basic Engineering and Applied Sciences, Agriculture Engineering College and Research Institute, Tamil Nadu Agricultural University, Kumulur, Trichy (Tamil Nadu), India

\section{G. Thiyagarajan}

Water Technology Centre, Tamil Nadu Agricultural University, Coimbatore (Tamil Nadu), India

${ }^{*}$ Corresponding author. E-Mail: sujitha047@gmail.com

\begin{abstract}
Crop water consumption (ETc) varies from region to region depending on crop type, growth stages, soil, and climate conditions. In order to obtain full yield and avoid unnecessary water usage, the water demand of the cultivated plants should be accurately calculated, and irrigation water should be applied in accordance with plant needs. In this, the study was carried out in field No.C3 of Central farm at Agricultural Engineering College and Research Institute, Kumulur, Trichy district to determine the growth stage-specific crop coefficient $(K c)$ and pan coefficient $(K p)$ for the greenhouse grown marigold (Tagetes erecta (L.). Since, a large area was occupied by a ClassA pan, the reduced-size evaporative pans (20 and $60 \mathrm{~cm}$ compared with Class A pan) was used and pan coefficient was determined as 0.93 and 0.96 respectively. A pan coefficient $(\mathrm{Kp})$ was used to convert pan evaporation (Epan) to grass reference evapotranspiration (ETo). Based on the tensiometer readings, the depleted moisture content was taken to reckon the crop coefficient for different growth stage. The results revealed that crop coefficient $(K c)$ for marigold was observed as 0.37 during the initial stage $\left(\mathrm{Kc}_{\text {in }}\right), 0.8$ during mid-stage $\left(\mathrm{Kc}_{\text {mid }}\right)$ and 0.47 $\left(\mathrm{Kc}_{\text {fin }}\right)$ during the final stage. These results would be helpful for crop water requirement and irrigation scheduling for similar condition.
\end{abstract}

Keywords: Crop Coefficient, Crop Evapotranspiration, Greenhouse, Marigold, Pan Coefficient

\section{INTRODUCTION}

Irrigation management directly affects crop growth and can contribute to increases in vegetable production in the sense of qualitatively and quantitatively (Dukes et al.. 2010). Deficit irrigation generally results in lower crop yields and quality, while surplus irrigation can lead to increased vulnerability of crops to disease (Pardossi et al., 2009). Irrigation management, therefore, also needs to be effective to help the environmental impact and encourage the sustainable use of resources (Montesano et al., 2015). In recent greenhouse industry has enormously popularized in many parts of the world. Many of these are low-cost, plastic film-covered structures with no active climate control systems and drip irrigated, soilgrown crops (Perez-Parra et al., 2004). The microclimate prevailing inside the greenhouse, such

\section{Article Info}

https://doi.org/10.31018/

jans.vi.2264

Received: April 28, 2020

Revised: May 10, 2020

Accepted: May 16, 2020

\section{How to Cite}

Sujitha, E. et al. (2020). Estimation of crop coefficient for Marigold (Tagetes erecta (L.)) under drip irrigated greenhouse. Journal of Applied and Natural Science, 12(2): 128 - 132 https://doi.org/10.31018/ jans.vi.2264 
sonable cost, ease of use, high precision and direct measurement of matrix potential, and also because they are not affected by temperature and soil osmotic potential; (Thalheimer, 2003; Sarkar et al., 2008; Montesano et al., 2010) however, the probability of acquiring electronic data via differential pressure transducers makes the tensiometer ideal for automatic use. But even though, tensiometers must be carefully controlled to prevent air bubbles from developing in the shaft; they must be shielded from frost and require daily maintenance, for example, to refill the water in the tube. Today, Marigold (Tageteserecta (L.)) seems to have attained the cultural status of one of the most commercially profitable flowers across the world. From the point of view of commercial marketing and revenue generation, Marigold has the edge over the loose flowers in vogue, the rank order being followed by chrysanthemum, jasmine, tuberose, crossandra and barleria (Bhattacharjee, 2003). Besides, all the above it is being grown commercially as an important source of carotenoid pigments. For the poultry industry, marigold carotenoids are the key source of pigment as a feed additive for intensifying the yellow colour of egg yolks, broiler skin (Scott et al., 1968). The main demand for marigold today comes from the recent trend towards the use of natural dyes throughout the world. Presently, in our country, the commercial extraction of marigold carotenoids is done in Kerala, Telengana, Tamil Nadu and Karnataka. It is being regularly exported to Mexico, Peru, USA, Japan, Spain, Romania, Netherlands, Turkey, Poland, Italy, Australia, Canada, Africa etc. With the above considerations, the objective of the present study was aimed to determine the growth stage-specific crop coefficient $(K c)$ and pan coefficient $(K p)$ for the greenhouse grown marigold (Tagetes erecta) crop.

\section{MATERIALS AND METHODS}

The field experiment was conducted in field No.C3 of Central farm at Agricultural Engineering College and Research Institute, Kumulur, Trichy district. The experiment was carried out in a naturally ventilated greenhouse with the length $12 \mathrm{~m}$, width $6 \mathrm{~m}$ and height $4.5 \mathrm{~m}$. Marigold (Tagetes erecta (L.)) seedlings were transplanted in $30 \times 60 \mathrm{~cm}$ spacing.

Physical characteristics of the growing media like soil texture, bulk density, particle density, porosity, water holding capacity, field capacity, wilting point and soil moisture content were analyzed by the standard procedures (Keen and Rackzowski, 1921). Determination of field capacity and the wilting point was done by pressure plate apparatus (Cassel and Nielsen, 1986). Soil moisture content was determined by the gravimetric method (Michale, 2012).
Determination of the soil moisture characteristics curve by using Tensiometer: To determine moisture characteristics curve tensiometers were placed at root zone depths to measure the soil moisture tension. Irrigation was applied till tension reaches ' 0 ' atmosphere in vacuum gauge. After irrigation, soil samples were collected on a daily basis and the soil moisture content of the media was measured by using the gravimetric method. The tension was recorded for respective soil moisture content. This process was continued until it reached the permanent wilting point (Michale, $A$. M (2012). The calibration curve was drawn with observed tensiometer reading on $X$-axis and soil moisture content on $\mathrm{Y}$-axis. Based on this calibration curve irrigation was done when the tensiometer indicated that the metric suction had reached known prescribed values for the respective crops.

Pan evaporation: Pan diameter of $20 \mathrm{~cm}, 60 \mathrm{~cm}$ and $121 \mathrm{~cm}$ (Class A pan) were installed above the ground surface in the experiment plot. The increase or decrease in pan water level was recorded at 8.30 a.m and 4 p.m.

Soil moisture content-based irrigation scheduling: Irrigation scheduling was the estimation of at what time, what quantity and how often water to be applied to a crop. The aim was to optimize the efficiency of irrigation by adding the exact amount of water required to replenish the desired level of soil moisture.

$$
\mathrm{d}=\frac{(\text { F.C }- \text { W.P }) \times \mathrm{As} \times \mathrm{D}}{100} \times \mathrm{ASMD} \ldots(1)
$$

Where,

$\mathrm{d}=$ depth of water needed, $\mathrm{cm}$

F.C = Field capacity of the effective root zone, per cent dry basis

W.P $=$ Wilting point of the effective root zone, per cent dry basis

As = Apparent specific gravity of the soil in the effective root zone

$\mathrm{D}=$ Effective root zone depth, $\mathrm{cm}$

ASMD = Available Soil Moisture Depletion, $(50 \%$ moisture depletion is suggested as

the time to start irrigation to avoid crop stress Sandra Ibarra, 1997)

Aw $=$ area of wetting, $\mathrm{cm}^{2}$

Water requirement in Volume basis $=A w X d$

Tension measurements were useful in deciding when to irrigate. The apparatus was loaded with distilled water and taped repeatedly till the tensiometer eliminated the air bubbles. Tensiometer was installed to root zone depth where moisture is to be determined. First watering was done up to the saturation level and transplanting were done. The tension was recorded by tensiometer on a daily basis and respective soil moisture content was noted from Figure 1. When the soil moisture content reached a calculated amount of $50 \%$ ASMD the depleted amount of moisture was re- 
filled as irrigation.

Depth of water depleted $(\mathrm{d}), \mathrm{cm}=\frac{\left(\mathrm{MC}_{\mathrm{i}}-\mathrm{MC}_{50 \% \mathrm{ASM}}\right)}{100} \times \mathrm{D} \times \mathrm{As}--------(2)$

Where,

$\mathrm{d}=$ depth of water depleted

$M C_{i}=$ Initial moisture content after irrigation

MC $50 \%$ ASDM $=$ Moisture content at $50 \%$ of allowable soil moisture depletion

$\mathrm{D}=$ Depth of effective root zone, $\mathrm{m}$

Pan evaporation coefficient: The term pan coefficient $(\mathrm{Kp})$ is a major component of irrigated crop in water management and was used to transform pan evaporation (Epan) into grass-reference evapotranspiration (ETo), (Flvioand Folegatti, 2003; Doorenbos and Pruitt 1977). Because of the large area occupied by a class-A pan, alternative methods have been sought to estimate ETo inside greenhouses. Among them, the reduced-size pan deserved special attention (Carolina, 2003). Studies conducted in recent years have revealed that reduced-size evaporative pans can be utilized for irrigation scheduling in the greenhouse conditions. In this study for practical applicability, the reduced pan was used $(20 \mathrm{~cm}, 60 \mathrm{~cm}$ compared with class A pan) to measure evaporation. The Class A pan and reduced pan $(20 \mathrm{~cm}$ and $60 \mathrm{~cm})$ were installed inside the greenhouse. Evaporation was recorded from class-A pan and reduced pan (20 $\mathrm{cm}$ and $60 \mathrm{~cm}$ ). The pan coefficient value was determined with comparison of CAPi to $\mathrm{RPi}_{60 \mathrm{~cm}}$ andCAPi to $\mathrm{RPi}_{20 \mathrm{~cm}}$ to make use of reduced pan inside the greenhouse.

Determination of $\mathrm{Kc}$ value: The use of Kc produced in other regions as compared to those where it is calibrated does not meet the exact requirement for crop water and will result in either higher production costs due to an over-irrigation or reduced income due to irrigation deficit. Based on tensiometer value, when the $50 \%$ ASMD reaches the calculated amount of water was applied as irrigation. The depleted amount of irrigated water was recorded on daily basis by tensiometer reading and respective available moisture content was noted from the calibration curve. The

Table 1. Results of physical and chemical properties of the growing media in the research field.

\begin{tabular}{lll}
\hline Parameters & Units & $\begin{array}{l}\text { Growing } \\
\text { media }\end{array}$ \\
\hline Bulk Density & $\mathrm{g} \mathrm{cm}^{-3}$ & 1.42 \\
Particle Density & $\mathrm{g} \mathrm{cm}^{-3}$ & 2.6 \\
Porosity & $\%$ & 53 \\
MWHC & $\%$ & 33 \\
Vol. of water in air dried & $\%$ & 1.8 \\
sample & $\mathrm{dSm}^{-1}$ & 0.31 \\
EC & & 7.45 \\
pH & $\%$ & 23.6 \\
Field capacity @ 1/3 bar & $\%$ & 10 \\
Wilting point @ 15 bar & $\%$ & 13.6 \\
Available water (FC-WP) & $\%$ & $5 \times 10^{-6}$ \\
Permeability & $\mathrm{m} \mathrm{s}^{-1}$ & \\
\hline \hline
\end{tabular}

depleted moisture content was taken as ETc or crop water required. The ratio of crop evapotranspiration (ETc) by reference crop evapotranspiration (ETo) is known as crop coefficient

$$
\mathrm{K}_{\mathrm{C}}=\frac{\mathrm{ET}_{\mathrm{C}}}{\mathrm{ET}_{\mathrm{O}}}------------(3)
$$

Therefore, Kc values has been derived for the marigold crop with the above formula and depicted in Fig. 3.

\section{RESULTS AND DISCUSSION}

The results of the research study undertaken to find the crop coefficient $(\mathrm{Kc})$ and pan coefficient $(\mathrm{Kp})$ for marigold (Tagetes erecta) under Greenhouse cultivation indicated that the textural analysis of existing soil as per the triangular diagram showed sandy loam soil (sand $72.8 \%$, silt $16.1 \%$, clay $10.2 \%$ ). In order to improve water use efficiency, a better understanding of physical and hydraulic properties is needed (William, 1993). The analysis results are tabulated in Table 1. In this experiment, results showed that the physical and chemical properties of the growing media were in the normal ranges and proved to be the best media for cultivation of the marigold.

Determination of the soil moisture characteristics curve by using Tensiometer: Wet and dry weight of the media were analysed based on the gravimetric method and soil moisture content depleted. Characterstics curve between available soil moisture content $\mathrm{Vs}$ tension drawn for the growing media and $50 \%$ of ASMC was marked and is shown in Fig. 3. When the tension reached the $50 \%$ ASMC, the irrigations were done.

Pan evaporation: The pan coefficient $(K p)$ is the calibration coefficient used for predicting free water surface evaporation or reference crop evapotranspiration by pan evaporation. Because of the large area occupied by a class-A pan, alternative methods have been sought to estimate ETo that is re-

Table 2. Measurement of total pan evaporation (Ep), $\mathrm{mm}$ from $C A P_{\mathrm{i}}$, and Reduce pan $\left(\mathrm{RP}_{\mathrm{i} 60 \mathrm{~cm}}\right.$ and $\left.\mathrm{RP}_{\mathrm{i} 20 \mathrm{~cm}}\right)$ evaporimeter.

\begin{tabular}{lll}
\hline Different size Pan & $\begin{array}{l}\text { Pan } \\
\mathbf{m m}\end{array}$ & Evaporation, \\
CAP - Class A Pan Inside & 316.4 \\
$\begin{array}{l}\text { Greenhouse } \\
\mathrm{RP}_{\mathrm{i} 60 \mathrm{~cm}} \text { - Reduced Pan }(60\end{array}$ & 329.0 \\
$\mathrm{~cm} \varnothing)$ Inside greenhouse & \\
$\mathrm{RP}_{\mathrm{i} 20 \mathrm{~cm} \text { - Reduced Pan }(20}$ & 340.0 \\
$\mathrm{~cm}$ ) Inside greenhouse & \\
\hline
\end{tabular}

Table 3. Estimation of Pan Coefficient $(\mathrm{Kp})$ in greenhouse with a comparison of different size pan.

\begin{tabular}{lll}
\hline $\begin{array}{l}\text { Different size } \\
\text { Pan }\end{array}$ & $\mathbf{C A P}_{\mathbf{i}} \mathbf{X ~ R P}_{\mathbf{i 6 0} \mathbf{c m}}$ & $\mathbf{C A P}_{\mathbf{i}} \mathbf{X ~ R P}_{\mathbf{i} 20 \mathrm{~cm}}$ \\
\hline $\begin{array}{l}\text { Pan coeffi- } \\
\text { cient, Kp }\end{array}$ & 0.96 & 0.93 \\
\hline
\end{tabular}




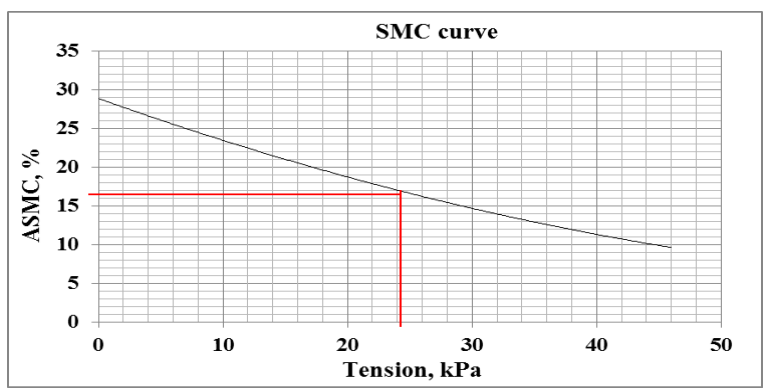

Fig. 1. Soil moisture characteristics curve for soil.

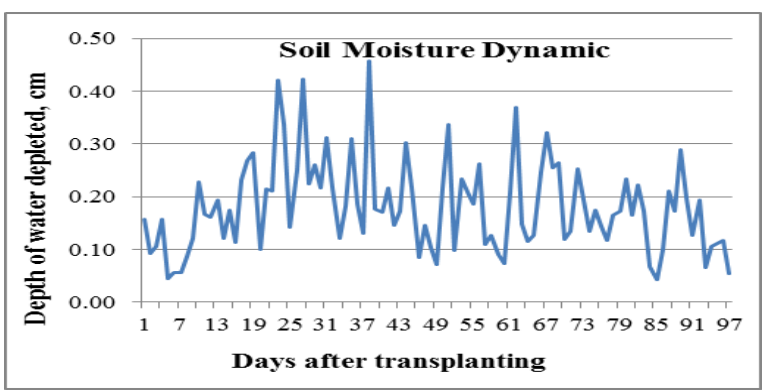

Fig. 2. Soil moisture dynamics for Marigold crop.

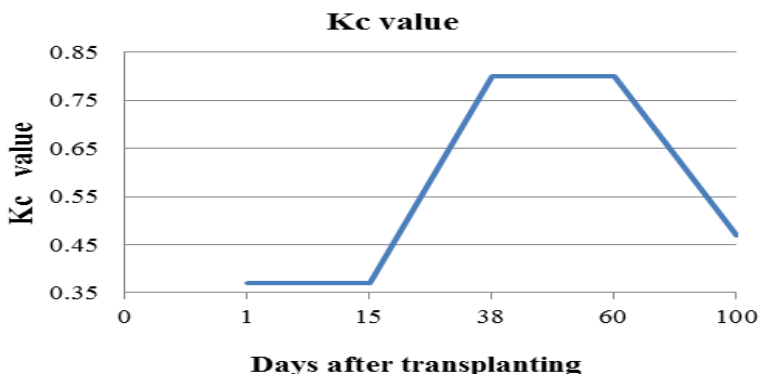

Fig. 3. Crop coefficient for Marigold crop.

duced pan. The Kp value was assumed to be 1.0, as recommended by Martinez-Raya and Castilla (1989) and Castilla et al. (1990) for greenhouse conditions. For outside greenhouse 0.8 was assumed, which is recommended by Doorenbos and Pruitt (1977). Evaporation was measured from the installed Class A pan $\left(\mathrm{CAP}_{\mathrm{i}}\right)$, Reduced pan $60 \mathrm{~cm}$ diameter $\left(\mathrm{RP}_{60 \mathrm{~cm}}\right)$ at 8.00 a.m and 4.00 p.m. Table2 shows the total evaporation, $\mathrm{mm}$ during the experiment in a different pan and Table 3 shows the pan coefficient which is determined based on the comparison of different size pan installed inside. Evaporation variation depends on the pan diameter, but there was not observed much difference in the greenhouse. During the cropping period, per day maximum and minimum pan evaporation $(\mathrm{mm})$ were observed from Class $A$ pan, $R_{60 \mathrm{~cm}}$ and $\mathrm{RP}_{20 \mathrm{~cm}}$ were 5.1 and $0.7,5.2$ and 0.7 and 5.3 and 0.8 respectively. The reduced pan $\mathrm{RP}_{\mathrm{i} 60 \mathrm{~cm}}$ and $\mathrm{RP}_{\mathrm{i} 20 \mathrm{~cm}}$ were measured as $3.8 \%$ and $6.9 \%$ higher evaporation than the Class A pan inside the greenhouse. (Amiri et al., 2011) Reduced pan has a low cost and is simple to use and occupies a small greenhouse area. Hence it is recommended to substitute RP inside the greenhouse instead of Class A pan.
Soil moisture dynamics: The evapotranspiration (ETc) of the marigold crop was determined as daily moisture content depleted, which is noted from the tensiometer inserted in the growing media for the full growing season. ETc value on daily basis varied from 0.04 to $0.46 \mathrm{~mm} \mathrm{day}^{-1}$.

Determination of crop coefficient (Kc) based on ETc and ETo for marigold: Crop coefficient value was estimated throughout the complete crop cycle. The average values of each stage were determined and are tabulated in Table 3. The crop coefficient for greenhouse soil was 0.37 during the initial stage $\left(\mathrm{Kc}_{\text {in }}\right), 0.8$ during mid-stage $\left(\mathrm{Kc}_{\mathrm{mid}}\right)$ to $0.47\left(\mathrm{Kc}_{\text {fin }}\right)$. During the initial stage (15 days) the plant, crop coefficient was found to be lower because of lesser ground cover and lower water requirement, but during the final stage (40 days), it was found more than initial stage. In mid-stage (45 days) it was found to be maximum. Similar results were found by Singh et al. (2016) conducted study in Field Water Management Laboratory of Agricultural and Food Engineering Department, Indian Institute of Technology, Kharagpur, India who reported that the crop coefficient for greenhouse condition was 0.48 to 0.6 during the initial stage, 0.6 to 0.86 during development stage, 0.87 to 0.96 during the middle stage and 0.96 to 0.76 during the late season of rose. Ertek et al. (2004) stated that ETc/Epan ratios varied for Squash from 0.2 to 1.16 during the growth season. These ratios increased from early to mid-season and later decreased from midseason to late-harvest. Mila et al. (2016) study was conducted to predict $\mathrm{Kc}$ value of sunflower using P-M method, FAO temperature method, FAO-Radiation method and Hargreaves method. Results revealed that $\mathrm{Kc}$ values for initial, mid and final stages were $0.46,1.55$ and $0.36,0.35,1.21$ and $0.31,0.34,1.03$ and $0.27,0.36,1.18$ and 0.3 respectively. The calculated values for the sunflower crop coefficients varied considerably at all levels from those recommended by the FAO. The differences were due to localisation and atmospheric effects on crop growth and yield. However, the approximate location-specific values of crop coefficients were used in irrigation preparation and crop water demand estimation and irrigation scheduling. As reference with many research results similar trends were observed in this study. In the crop grown period, crop coefficient was lowered in initial stage compared with the final stage and the highest value was observed in the mid-stage. Therefore, the estimated growth stage-specific crop coefficient value would be found helpful for optimum irrigation scheduling.

\section{Conclusion}

Experiments carried out on marigold (Tagetes erecta) crop in greenhouse showed that value of evapotranspiration in the different sized pan with 
minimal difference. ETc increased with the growth of the crop and reached its maximum at the stage when the plants' growth was most active. Estimated growth specific crop coefficient values were preferred to use for irrigation scheduling. Considering the variation in evapotranspiration from the panes, the Class A pan can be replaced with the reduced pan inside to estimate ETo. Reduced pan was affordable and simple to use and occupied a tiny area in the greenhouse, so it is suggested to replace the $20 \mathrm{~cm}$ pan inside the greenhouse instead of the Class A pan.

\section{REFERENCES}

1. Amiri, M.J., J. Abedi-Koupai and S.S. Eslamian. (2011). Evaluation of the performance of evaporation pans in greenhouse environment. Journal of Science and Technology of Greenhouse Culture, 2008 9082.

2. Bhattacharjee, S.K. (2003). Post harvest life and quality of rose cut flowers as affected by pre cooling, storage and gamma irradiation. Indian Rose Annual, 19: 116-143

3. Cassel, D. K., and Nielsen, D. R. (1986). Field capacity and available water capacity. Methods of Soil Analysis: Part 1-Physical and Mineralogical Methods, (Methods of soil), 901-926. https:// doi.org/10.2136/sssabookser5.1.2ed.c36

4. Carolina Fernandes, Jose Eduardo Cora and Jairo Augusto Campos de Araujo.(2003). Reference evapotranspiration estimation inside greenhouses. Scientia Agricola., 60(3): 591-594. https://doi.org/10.1590/ S0103-90162003000300027.

5. Doorenbos.J and Pruitt W. O. (1977). Crop water requirements. FAO Irrigation and Drainage Paper, Rome. No: 24 - 179.

6. Ertek A., S. Şensoy, C. Kucukyumuk and I. Gedik. (2004). Irrigation Frequency and Amount Affect Yield Components of Summer Squash (Cucurbitapepo L.). Agric. Water Manage., 67: 63-76. DOI: 10.1016/ j.agwat.2003.12.004

7. Flvio F. Blanco and V. Folegatti. (2003). Evapotranspiration and crop coefficient of cucumber in greenhouse, Revista Brasileira de Engenharia Agrícolae Ambiental, 7(2): 285-291. https://doi.org/10.1590/ S1415-43662003000200017.

8. Keen, B. A., and Raczkowski, H. (1921). The relation between the clay content and certain physical properties of a soil. The Journal of Agricultural Science, 11(4): 441-449

9. Martinez-Raya, A and N. Castilla. (1989). Evapotranspiracion del pimiento en invernadero en Almeria. ITEA: Produccion Vegetal, Zaragoza.,85: 57-62.

10.Michael, A.M. 2012. Irrigation Theory and Practice. Text book. Vikas Publishing. 2Nd Edn.

11.Michael D. Dukes, L. Zotarelli and Kelly T. Morgan.
(2010). Use of Irrigation Technologies for Vegetable Crops in Florida, Hort.Technology, 0(1). https:// doi.org/10.21273/HORTTECH.20.1.133

12.Mila.A.J., A.R. Akanda, S.K. Biswas and M.H. Ali. (2016). Crop co-efficient values of sunflower for different growth stages by lysimeter study. British Journal of Environment and Climate Change, 6(1): 53-63. DOI: 10.9734/BJECC/2016/24246

13. Montesano, F., A. Parente and P. Santamaria (2010). Closed cycle sub irrigation with low concentration nutrient solution can be used for soilless tomato production in saline conditions. Sci. Hortic., 124: 338-344. DOI : 10.1016/j.scienta.2010.01.017

14.Montesano, F.F., A. Parente, N. Lamaddalena, M. Todorovic and L. Trotta, (eds.).(2015). Introduction in Modern Technologies, Strategies and Tools or Sustainable Irrigation Management and Governance in Mediterranean Agriculture (IrriMed2015), Proceedings-Abstr.,(Valenzano, IT: CIHEAM)., 19-20.

15.Pardossi, A., L. Incrocci, G. Incrocci, F. Malorgio, P. Battista and L. Bacci. (2009). Root zone sensors for irrigation management in intensive agriculture. Sensors.,9: 2809 -2835. DOI: 10.3390/s90402809

16.Pérez-Parra, J., E. Baeza, J.I. Montero and B. Bailey. (2004). Natural ventilation of parral greenhouses. Biosystem Engineering., 87:355-366. DOI: 10.1016/ j.biosystemseng.2003.12.004.

17.Sandra Ibarra. 1997. Soil moisture and tensiometer measurements made to assist the management of supplementary Irrigation of maize in eastern Ontario, Ph.D Thesis. Department of Agricultural and Biosystems Engineering, Macdonald Campus of McGill University, Montreal.

18.Sarkar, S., Y. Kiriiwa, M. Endo, S. Uchino and A. Nukaya (2008). Possibility of high soluble solid content tomato production under water stress conditions controlled by matric potential. J. Japan. Soc. Hort. Sci.,77: 251-258.

19.Scott, M. L., I. Ascarelli and G. Olson.(1968). Studies of egg yolk pigmentation. Poult. Sci., 47: 863-872. https://doi.org/10.3382/ps.0470863

20.Singh, V.K, K.N Tiwari and D.T Santosh (2016). Estimation of crop coefficient and water requirement of dutch roses (Rosa hybrid) under greenhouse and open field conditions. Irrigation Drainage Sys Eng., 5: 169. DOI: $10.4172 / 2168-9768.1000169$

21.Thalheimer, M. (2003). Tensiometer modification for diminishing errors due to the fluctuating inner water column. Soil Sci. Soc. Am. J.,67: 737-739. DOI: 10.2136/sssaj2003.0737

22.Whalley, W.R., E.S. Ober, and M. Jenkins. (2013). Measurement of the matric potential of soil water in the rhizosphere. J.Exp.Bot., 64: 3951-3396. DOI: 10.1093/jxb/ert044

23. William. C. Fonteno.(1993). Problems and consideration in determining the physical properties of horticultural substrate. Acta Horticulture., 342: 197-204. 